\title{
Start to Finish: The Effect of Sportswriter and Reader Gender on Perception of Female Athletes
}

\author{
Rebecca Dell, Cynthia M. Frisby \\ University of Missouri, Columbia, MO, USA \\ Email: FrisbyC@missouri.edu
}

How to cite this paper: Dell, R., \& Frisby, C. M. (2017). Start to Finish: The Effect of Sportswriter and Reader Gender on Perception of Female Athletes. Advances in Journalism and Communication, 5, 236-255. https://doi.org/10.4236/ajc.2017.54014

Received: September 4, 2017

Accepted: December 17, 2017

Published: December 20, 2017

Copyright ( 2017 by authors and Scientific Research Publishing Inc. This work is licensed under the Creative Commons Attribution International License (CC BY 4.0).

http://creativecommons.org/licenses/by/4.0/

\section{(c) (i) Open Access}

\begin{abstract}
Poor portrayal and perception of female athletes has a host of negative outcomes, such as objectification of women (Daniels, 2009; Daniels \& Wartena, 2011) and negative reader judgment of female athletes (Knight \& Giuliano, 2001). This study examines whether the gender of the sportswriter and reader affect the perception of female athletes (in terms of athleticism, respectability and interest in the sport). No significant interaction was found between sportswriter and reader gender, but a main effect was found for reader gender wherein women tend to think more highly of the athleticism and respectability of female athletes. Women were also more likely to view the sportswriter as credible; and higher credibility was positively correlated with perceptions of the athlete's athleticism and respectability.
\end{abstract}

\section{Keywords}

Female Athlete's Athleticism, Perceptions of Female Athletes, Objectification of Women, Reader Judgment of Female Athletes, Gender and Sportswriter Perception of Female Athletes

\section{Introduction}

Research shows that the portrayal and perception of female athletes contains a host of negative outcomes, such as the sexualization and objectification of women (Daniels, 2009; Daniels \& Warena, 2011) and negative reader judgment of female athletes (Knight \& Giuliano, 2001). This study examines whether the gender of the sportswriter and reader affect the perception of female athletes (in terms of athleticism, respectability and interest in the sport). In order to better understand 
how the gender of the writer can impact the perception of the athlete; an experiment was conducted using a posttest-only control-group design. Using a 3 (male sportswriter vs. female sportswriter vs. no sportswriter listed) $\times 2$ (male reader vs. female reader) between-subjects factorial experiment, the research investigates the affect that gender of the sportswriter has on how male and female readers think of news concerning a female athlete. Additional factors are examined, such as the credibility of male versus female sportswriters. This exploration incorporates theories from multiple studies on gender and sports media.

The main independent variables for this study are source gender and reader gender, which respondents self-report. The dependent variables, which are measured with an online survey instrument comprised of questions and Likert scales, are the perceived athleticism and respectability of the athlete in the story, as well as the reader interest in the sport and athlete after reading the story. The study is a controlled experiment, a method chosen to isolate the variables to the point where a correlation can be found or not found between writer gender and reader perceptions, thus providing practical applications.

Sports writers and editors have direct control over what material they use and how they use it. But editors, publishers and designers can also choose the gender of the writer, and they can consider the impact that articles written about female athletes are likely to have on their readership. Ultimately, this study and others like it should contribute to a scholarly attempt at improving gender equality in America, especially in sports and sports media, so that female athletes are perceived with the same respect and seriousness that male athletes are perceived with.

In order to meet the goals stated above, the researcher conducted a betweensubjects posttest-only experiment to examine whether sportswriter gender affects reader perception of female athlete athleticism, respectability and interest (i.e. the interest the reader has in the athlete and her sport); whether the reader's own gender affects his or her perception of those same dependent variables; and whether there is a significant interaction between sportswriter and reader gender affecting those dependent variables.

\section{Literature Review}

Over the past thirty-five years or so, research on the effect of journalist gender on audience perceptions of variables such as source credibility and reader interest in the topic have resulted in varied findings. Some researchers have postulated that surprising results may be due to changing gender attitudes (Greer \& Jones, 2012); others say maybe unexpected results are due to social desirability in this case, that twenty-first century men are afraid to come across as misogynistic and thus over-correct when responding to surveys (Flanagin \& Metzger, 2003).

This study creates a very specific iteration of source gender research, as the variations in past research suggest that old results cannot be extrapolated to different situations. Past research on source and audience gender, source credibility and perceptions of athletes provide the foundation and help direct the method, 
an experiment, for this study.

\subsection{Author Gender and Audience Gender}

The 2010 Global Media Monitoring Project found that worldwide, men report 62\% of the stories about celebrity, arts and sport; male sports professionals are the subjects of $89 \%$ of stories about sports professionals (Macharia et al., 2010). According to a study conducted on 150 news sources by The Institute for Diversity and Ethics in Sport, only 9.6\% of sports editor positions and 17.2\% of assistant sports editor positions are held by women (Lapchick et al., 2013).

Stories by women are more likely to cover females, and female reporters challenge stereotypes more than men (Brann \& Himes, 2010; Macharia et al., 2010). Rodgers and Thorson (2003) offered two models to explain the differing results of media studies about author gender: the gender model of socialization-indicating men and women work differently because they have different values-mediated by the job model, which indicates men and women work similarly if their work organizational structures are comparable. They found that women tend to use a more diverse source pool and stereotype less than men (Rodgers \& Thorson, 2003). Kaiser (2011) found, in a two-part, longitudinal, content-analysis study, that changing worldviews influenced females' coverage of Title IX. But Rodgers and Thorson (2003) noted that people assume author gender changes the content of media and, citing those mixed results in studies examining reporter gender and sourcing, question whether men and women really report differently.

Thus, this study explores the space between those seemingly contradictory conclusions. Since author gender affects the content of the story, it is plausible that, from prior reading experience, audiences expect the content to differ when reading stories by men versus women.

White and Andsager (1991) found people prefer to hear arguments from members of their own groups; thus, males prefer columns written by men and females prefer columns written by women. Participants regarded columns written by their own gender to be more interesting than columns written by the opposite gender, or they "ascribed interesting columns to writers of their own gender" (White \& Andsager, 1991, p. 718).

White and Andsager (1991) used theories of heuristic processing and the Elaboration Likelihood Model to explain their findings. Heuristic processing is the idea that people use associations to make decisions where they don't have motivation or ability to deeply consider the decision (Chaiken \& Ledgerwood, 2007), and the Elaboration Likelihood Model helps synthesize conflicting findings in persuasion literature by saying that depending on how much brain power people are willing to put into responding to something, they'll process differently and come away with different responses (DeMarree \& Petty, 2007). The Elaboration Likelihood Model, in particular, "suggests people will think about a message as a function of their motivation and of their ability to do so" (White \& Andsager, 
1991, p. 711). They may make decisions using central processing, where they carefully consider each point, or peripheral processing, where they tend to use more heuristics (White \& Andsager, 1991, p. 711). This study examines readers' need for cognition as a way of measuring whether the decisions they make are peripheral, which is layered onto their perceptions of female athletes based on sportswriter gender.

Ordman and Zillmann (1994) found that female reporters are at a disadvantage when wanting to be viewed as expert sports reporters because they are viewed as less competent and persuasive, regardless of sport gender. If the writer is viewed as less competent, then, is the subject of the story viewed as less competent? Greer \& Jones (2012) examined whether US audiences accept female broadcasters analyzing traditionally male sports, contrary to the contentions of media executives, as well as whether male broadcasters analyzing traditionally male sports are seen as more competent, likeable and whether audiences agree with their analyses. Greer and Jones's (2012) findings were opposite of previous research: participants rated female broadcasters as more competent across the board, which the researchers attributed both to limitations of the study and, possibly, to changing gender attitudes.

There is some evidence that the Communication Accommodation Theory could explain the nuanced reaction of audiences to male versus female sports reporters (Mastro et al., 2012). CAT was developed by Howard Giles in the early 1970s and shows that people tend to shrink or enlarge social distance when they communicate with one another. That converging or diverging depends on how much one person wants another's approval. "CAT contends that people accommodate not necessarily where others' communication patterns actually are but where they believe them to be; stereotypes often dictate how others sound to us" (Sprecher \& Reis, 2009, p. 266). Mastro et al. (2012) stretched this theory beyond interpersonal communications and applied it to mass media, looking to see how sports reporters are perceived based on whether they are the same gender (and, in that study, race) as the predominant participant in the sport being covered. Mastro et al. (2012) argued that because mass media producers do not interact with their audiences face-to-face, they use audience stereotypes to converge their messages with audience expectations, which provides cues on how audiences should evaluate the reporter and message.

This study takes Mastro's work a degree further. Mastro wrote, “One can assume that the features of group memberships (e.g., gender, race) would also contribute to perceptions regarding convergence" (Mastro et al., 2012, p. 461). If sportswriters play to stereotypes to better converge between media producers and consumers (Mastro et al., 2012, pp. 461-461), then perhaps audiences expect that accommodation. "Findings indicate that norms/stereotypes about gender, race, and sports can influence perceptions of news reporters (as well as the value of the information they provide), in a manner consistent with CAT" (Mastro et al., 2012, p. 468). This study looks at what impact convergence would have on 
perception not of the media producers themselves, but on the athletes in the stories.

It is possible that male and female sportswriters are rejecting traditional frames in sports (Kian \& Hardin, 2009). In Kian and Hardin's (2009) content analysis of NCAA men's and women's basketball tournament coverage, they found that female authors were more likely to write about female sports than men were, which "could be interpreted as evidence of the relatively low status of women in sports departments, as they were assigned to cover women's games while their male colleagues covered the men's tournament" - a statement which, in itself, ascribes low value to women's sports (Kian \& Hardin, 2009, p. 197).

\subsection{Credibility}

In this study, the credibility of the sportswriter was examined as a possible mediating factor in how readers perceive female athletes. Credibility was chosen because of its possible correlations with sportswriter and reader gender (see Brann \& Himes, 2010; Gunther, Kautz, \& Roth, 2011).

Gender has a mixed research history as a credibility indicator. Despite their findings that readers found columns written by their own gender to be more interesting than columns written by someone of the opposite gender, White and Andsager (1991) found no difference between genders for columnist credibility, and no difference based on topic. Other researchers cite the same varying findings throughout the literature (Flanagin \& Metzger, 2003).

On a more basic note, Ohanian (1990, pp. 41-42) defined source credibility as "a communicator's positive characteristics that affect the receiver's acceptance of a message", although she noted that higher credibility does not always lead to more effective persuasion or behavioral compliance than low credibility does. Ohanian (1990, p. 40) noted that the discrepancy in previous research scales for source credibility could account for the discrepancies in research on source credibility's effect on consumer attitude.

Morin, Ivory, \& Tubbs (2012) distilled two common factors in most source credibility research: trustworthiness and competence (Morin, Ivory, \& Tubbs, 2012, p. 414). Ohanian referenced Hovland, Janis, and Kelly's (1953) definitions for approximately those two factors: expertise as "the extent to which a communicator is perceived to be a source of valid assertions", and trustworthiness as "the degree of confidence in the communicator's intent to communicate the assertions he considers the most valid" (Ohanian, 1990, p. 41; see also Crisci \& Kassinove, 1973). Although Ohanian used attractiveness items as part of her hypothesized factors, these were excluded from this study because this study concerns print materials when the author has no photo or association (such as being a celebrity) that would give the reader a reasonable indication of his or her attractiveness.

One way gender could affect how readers perceive female athletes is through persuasion on the basis of similarity with the source Gender is a signifier that 
acts "as a marker of similarity or dissimilarity with audience members" (Flanagin \& Metzger, 2003, p. 684). Friedman, Santeramo, \& Traina (1978, p. 293) found that trust correlated with similarity, or "Degree to which the celebrity is thought to be similar to the subject". Teenagers evaluated anti-alcohol messages as more credible when the message came from someone of the same gender as the teenager (Bochner, 1994; Brock, 1965; Daniels, 2009; Daniels \& Wartena, 2011). Flanagin \& Metzger (2003) cited Brock (1965), writing that "persuasiveness can be enhanced by similarity between source and receiver" (Flanagin \& Metzger, 2003, p. 685). Bochner (1994) used the match/mismatch concept that individuals classify others based on "us", "them", or "neutral", and then view the "us" as having similar values and a common fate.

But there are also suggestions that the difference in gendered credibility ratings is due to underlying gender tendency differences. In a study on source gender, men indicated websites of both males and females were more credible than women did; men judged the female site and its message as most credible, while women did the opposite (Armstrong \& McAdams, 2009; Bates, Romina, Ahmed, \& Hopson, 2006; Brann \& Himea, 2010; Flanagin \& Metzger, 2003). One explanation that the authors offered is that the men, typically being the perpetrators of sexism in our culture, might have feared seeming sexist and thus veered away from anything that could be construed as sexism (Flanagin \& Metzger, 2003). If this is true, then the present study should show that men view female athletes as more athletic and respectable when written about by a female writer. However, Bochner (1994) also found that boys rated both male and female speakers as more credible than girls did, and girls and boys rated female speakers as more credible than male speakers.

As evidenced in Morin, Ivory, \& Tubbs (2012) and Ohanian (1990), much of advertising research is concerned with how source credibility affects source persuasiveness. This study, however, is not concerned with persuading readers to appreciate female athletes, but instead aims to examine the interplay in source attributes that may affect readers' perceptions of the female athlete where it would not affect perception of the male athlete (although, due to fiscal and time limitations, articles about male athletes are not being included in this study).

\subsection{Research Questions}

The purpose of this study is to examine the influence of sportswriter gender on how readers view female athletes. To do so, the following research questions will be addressed:

- RQ1: How does a sportswriter's gender affect female readers' perception of female athletes, in terms of athleticism, respectability and interest?

- RQ2: How does a sportswriter's gender affect male readers' perception of female athletes, in terms of athleticism, respectability and interest?

\section{Methods}

To answer the aforementioned research questions, an experiment was conducted 
using a posttest-only control-group design. It was a 3 (male sportswriter vs. female sportswriter vs. no sportswriter listed) $\times 2$ (male reader vs. female reader) between-subjects factorial experiment. The experiment was conducted via a stimulus and questionnaire online using Qualtrics software (for the stimulus) and Amazon Mechanical Turk (for sampling).

\subsection{Independent Variables}

The independent variables were operationalized as follows.

\subsubsection{Sportswriter Gender}

- The sportswriter gender was operationalized as a female byline (Allison Copen), a male byline (Andrew Copen) or no byline. To ensure that readers noticed the byline, the questions were phrased as being about the sportswriter's article (such as, “After reading Allison Copen's tennis article, do you...”). Many online and opinion sports pieces run an author thumbnail with each article and byline. This study did not use photos in order to eliminate attractiveness confounds.

\subsubsection{Reader Gender}

Toward the end of the survey, respondents were asked: "With which gender do you primarily identify"? The answer options were "Male" and "Female".

By examining sportswriter and reader gender, this design allowed the researcher to assess both the possible effect of author gender on readers and the possible interactions between reader and author gender.

\subsubsection{Experimental Stimuli}

For the stimulus, the researcher found an AP story about a professional tennis match and modified it. Modifications included inventing names for each of the players and making the tennis match NCAA-level, rather than professional, so that the average reader was less likely to be familiar with real players in the league. The researcher shortened the piece significantly, edited it for clarity and ease of reading, and cut out anything that felt like a framing device or stereotypically girly. This was to prevent swaying the reader based on content (for example, the word "affair" was changed to "event", and a paragraph in the original article where the player complained to refs about "twirling lights" was removed). As a control, the stimulus materials, or article text and headlines, were the same for all three conditions. The only difference was the byline, which was either Allison Copen, Andrew Copen or absent.

\subsection{Study Validity}

Threats to internal validity included selection (in general, only a certain type of person may feel inclined to participate in an online experiment) and diffusion of treatment (it is possible that some participants told others about the study; however, the data was gathered so quickly it is unlikely that many respondents could have told others about it in time for them to take the survey). Because the expe- 
riment was conducted online, participation was restricted to people with computer and Internet access. There is always the possibility some participants lied in their responses.

Threats to external validity could have included interaction of history and treatment. For example, public opinion about female athletes may shift with time, perhaps becoming more intense around events such as the Olympics, when female athletes such as Shawn Johnson, Missy Franklin, Kerri Walsh Jennings and Misty-May Treanor are elevated as worldwide celebrities. However, this research was conducted in an Olympic off-year, and not close to a major championship, so this research speaks to female athlete perception in a non-hyped season.

There were no follow-up procedures to compare respondents with non-respondents, because the survey was available via a service (Amazon Mechanical Turk) where the researcher did not have access to the contact information of potential respondents. The data was collected anonymously.

As an extra control measure, this study asked readers for issue salience to discover how sports relate to their lives. It was measured by asking respondents to rate how relevant articles about sports are to their own lives; how interesting they generally find articles about sports; how much they enjoy articles about sports; and how important they find articles about sports (7-point issue salience scale from Flanagin \& Metzger; Cronbach's alpha $=.76$ ) (Flanagin \& Metzger, 2003, p. 693).

In order to keep respondents from guessing the intent of the study, several sports-related questions were added as decoy questions. Some of these questions, however, were still relevant. Extra questions or areas on the survey included:

A place to check the boxes next to any sport participants had participated in.

"Does this article by encourage you to begin playing tennis or training for a half-marathon?"

"Which of the following factors are most important to you for sports footwear?"

"If you were to write a comment on this story, what would it be?"

"Given the choice, I would prefer to watch:" (ESPN, FOX Sports or Neither).

"Given the choice, I would pay to watch a sports network on my phone."

"Given the choice, I would prefer to get sports news from a:" (Male sports broadcaster/Female sports broadcaster, Male sportswriter/Female sportswriter, Male sports radio host/Female sports radio host).

\subsection{Participants}

The population for this experiment was obtained from the online service Amazon Mechanical Turk. This population is appropriate for this study because it aims to show attitudes of average people in the United States who are at least media-savvy enough to find and read a story about a female athlete.

The researcher paid for 310 respondents and received 312 (with one removed 
because he or she decided to withdraw his or her data), with the goal of approximately 50 males and 50 females per condition. This is based on the sample size in Bochner's 1994 study.

\subsection{Outcome Measures}

To measure the dependent variables in this study, the following operational definitions and measures were used.

\subsubsection{Athleticism (Cronbach's Alpha = .93)}

Readers' perceptions of the athlete's respectability were measured by how athletic, competitive, talented, serious about sports and dedicated to sports she appeared. Each item was measured on 7-point Likert scale where 1 was "Not at all" and 7 was "Very much". This measure was adapted from a scale from Knight \& Giuliano (2003, p. 275; note that Knight \& Giuliano used a 10-point Likert scale).

\subsubsection{Respectability (Cronbach's Alpha $=.90$ )}

Readers' perceptions of the athlete's respectability were measured by how respectable and ambitious the athlete appeared, as well as by how much she seemed to act as a leader, seemed a good representative of her team and seemed a good role model. Each item was measured on a 7-point Likert scale where 1 was "Not at all" and 7 was "Very much". This measure was adapted from a scale from Knight \& Giuliano (2003, p. 275; note that Knight \& Giuliano used a 10-point Likert scale).

\subsubsection{Interest (Pearson's $r=.77$ )}

Readers' interest in the athlete and her sport was measured by how interested the reader was in reading more about the athlete and how interested the reader would be in watching the sport the athlete plays. Each item was measured on a 7-point Likert scale where 1 was "Not at all" and 7 was "Very much". This measure was adapted from a scale with a Cronbach's alpha of 87 (Knight \& Giuliano, 2003, p. 275; note that Knight \& Giuliano used a 10-point Likert scale and one additional item that did not make sense in terms of face validity).

\subsubsection{Credibility (of Author) (Cronbach's Alpha = .95)}

The credibility of the reporter was also measured as a mitigating factor. The following operational measure was used.

General author credibility was measured by how believable, trustworthy, competent and credible readers thought the sportswriter was. This scale was used by Morin, Ivory, \& Tubbs (2012, pp. 416-417).

Two other scales were used to measure participants' need for cognition and sexism.

\subsubsection{Need for Cognition (of Respondent) (Cronbach's Alpha $=$.95)}

Participants' need for cognition was measured using a need for cognition scale 
originally developed by Cacioppo \& Petty (1982) and later refined to 18 items (Cacioppo, Petty, \& Kao, 1984).

\subsubsection{Sexism (of Respondent) (Cronbach's Alpha $=.78$ )}

Sexism of respondent was gauged with a truncated version of the Ambivalent Sexism Inventory, designed to measure "attitudes toward women" (Glick \& Fiske, 1996, p. 509). One item was used to gauge hostile sexism ("Women are too easily offended."). Under the benevolent sexism umbrella, items measured protective paternalism ("Men should sacrifice to provide for women."), complementary gender differentiation ("Women have a more refined sense of taste than men."), and heterosexual intimacy ("Despite accomplishment, men are incomplete without women."). Each of these measures was pulled from the ASI (Glick \& Fiske, 1996, p. 500) to get a general feel for sexism among participants, not to garner a thorough analysis of sexism among participants.

\subsubsection{Treatment: Experiment}

The first independent variable, sportswriter gender, was administered when Qualtrics randomly sorted participants into one of three experimental conditions. One group of respondents saw a female byline; one saw a male byline; and one did not see a byline. The second independent variable, reader gender, was self-reported by the participant in a demographic question toward the end of the instrument.

\subsection{Data Analysis}

SPSS software was used for data analysis. Cronbach's alpha was tested for each dependent variable (interesting, athletic and respectable) as a measure of internal reliability. All the dependent variables were measured on an interval scale, so the data would meet the basic assumptions of Cronbach's alpha. The expected Cronbach's alpha for each of the dependent variable scales was greater than .70 .

Next, a factorial $(3 \times 2)$ ANOVA was run. This test was chosen because it is the simplest inferential analysis to run for between-subjects data with two or more independent variables, and it measures the effects of each independent variable as well as the interaction between the independent variables (Cronk, 2012, p. 74).

This analysis showed whether sportswriter gender and reader gender had an effect on perception of the female athlete. This test also showed whether there was a significant interaction between sportswriter gender and reader gender when it came to how the reader perceived the female athlete.

An alpha level of $p \leq .05$ was chosen to determine significance. This was chosen rather than $p \leq .01$ or $p \leq .001$ because the literature is too conflicted to point to an obvious outcome for the data.

\section{Results}

The research questions boil down to this: How do sportswriter gender and read- 
er gender affect female and male readers' perceptions of female athletes?

\subsection{ANOVA Analyses of Main Effects and Interactions}

In order to start answering the research questions, the data were analyzed using a 3 (sportswriter gender) $\times 2$ (reader gender) between-subjects factorial ANOVA, comparing the perceptions of the female athlete's athleticism by men and women who read the articles with different bylines. A significant main effect for reader gender was found $(F(1305)=.65, p<.05)$ (see Table 1$)$. There was no significant main effect for sportswriter gender, and the interaction was not significant.

The main effect for reader gender means that female readers perceived the athlete to be slightly more athletic $(m=6.45, s d=.08)$ than male readers did $(m=$ 6.20, $s d=.06)$, as shown in Table 2.

Another 3 (sportswriter gender) $\times 2$ (reader gender) between-subjects factorial ANOVA was calculated, this time to compare the perceptions of the female athlete's respectability by men and women who read the articles with different bylines. Again, a significant main effect for reader gender was found $(F(1305)=$ 12.22, $p=.01$ ) (see Table 3 ). There was no significant main effect for sportswriter gender, and the interaction was not significant.

Table 1. Univariate analysis of variance of perception of athleticism by writer gender and reader gender.

\begin{tabular}{cccccc}
\hline Source & df & SS & MS & F & $p$ \\
\hline Writer Gend & 2 & 1.50 & .75 & 1.08 & .34 \\
Reader Gend & 1 & 4.49 & 4.49 & 6.46 & $.01^{\star}$ \\
Writer Gend ${ }^{\star}$ Reader Gend & 2 & .34 & .17 & .25 & .78 \\
Total & 311 & 12520.72 & & & \\
\hline
\end{tabular}

${ }^{*} p<.05$.

Table 2. Reader gender effect on athleticism.

\begin{tabular}{ccccc}
\hline & & & \multicolumn{2}{c}{$95 \%$ Confidence interval } \\
\hline Gender of reader & $\mathrm{M}$ & SE & Lower bound & Upper bound \\
Female & 6.45 & .08 & 6.29 & 6.60 \\
Male & 6.20 & .06 & 6.08 & 6.32 \\
\hline
\end{tabular}

Table 3. Univariate analysis of variance of perception of respectability by writer gender and reader gender.

\begin{tabular}{cccccc}
\hline Source & $d f$ & $S S$ & $M S$ & $F$ & $p$ \\
\hline Writer Gend & 2 & 2.51 & 1.26 & 1.42 & .24 \\
Reader Gend & 1 & 10.79 & 10.79 & 12.22 & $.00^{* *}$ \\
Writer Gend ${ }^{*}$ Reader Gend & 2 & .44 & .22 & .25 & .78 \\
Total & 311 & $10,867.56$ & & & \\
\hline
\end{tabular}

${ }^{* *} p<.01$ 
The main effect for reader gender means female readers perceived the athlete to be slightly more respectable $(m=6.07, s d=.09)$ than male readers did $(m=$ 5.69, $s d=.07)$, as seen in Table 4.

Finally, a 3 (sportswriter gender) $\times 2$ (reader gender) between-subjects factorial ANOVA was calculated, comparing male and female reader interest in the sport and athlete after reading the articles with different bylines. This time, there were no significant results, although a main effect for reader gender approached significance with $p=.06$ (see Table 5). If that main effect had reached significance, it would mean that female readers were slightly more interested in the athlete and her sport $(m=3.85, s d=.16)$ than male readers were $(m=3.46, s d=.13)$.

\subsection{Correlations between Reader Participation in Sport and Interest}

There was a significant (though small) correlation between interest and reader's tennis participation and how relevant the reader thinks sports are to his or her life, as shown in Table 6. In Table 6, the variable "relevance" is from a four-item scale that asked participants to rate, on a seven-point scale, how relevant sports

Table 4. Reader gender effect on respectability.

\begin{tabular}{cccccc}
\hline Source & $d f$ & $S S$ & $M S$ & $F$ & $p$ \\
\hline Writer Gend & 2 & 1.72 & .86 & .28 & .76 \\
Reader Gend & 1 & 10.85 & 10.85 & 3.49 & .06 \\
Writer GendReader Gend & 2 & 2.49 & 1.24 & .40 & .67 \\
Total & 311 & 10867.56 & & & \\
\hline
\end{tabular}

Table 5. Univariate analysis of variance of perception of interest by writer gender and reader gender.

\begin{tabular}{ccccc}
\hline & & & \multicolumn{2}{c}{$95 \%$ Confidence interval } \\
\hline Gender of reader & $\mathrm{M}$ & SE & Lower bound & Upper bound \\
Female & 6.07 & .09 & 5.90 & 6.24 \\
Male & 5.69 & .07 & 5.55 & 5.82 \\
\hline
\end{tabular}

Table 6. Correlation between reader participation in sports and interest.

\begin{tabular}{ccc}
\hline & & Interest \\
\hline Relevance & Pearson correlation & $.35^{\star *}$ \\
Sig. (2-tailed) & .00 \\
Tennis participation & $\mathrm{N}$ & 311 \\
& Pearson correlation & $.26^{* *}$ \\
& Sig. (2-tailed) & .00 \\
$\mathrm{~N}$ & 311
\end{tabular}

${ }^{* *} p<.01$. 
are to their lives; whether they tend to think articles about sports are interesting; whether they enjoy articles about sports; and whether they think articles about sports are important (Cronbach's alpha $=.96$ ). The variable "tennis participation" is coded as yes/no, where participants had the option to check a box saying they have participated in tennis either as an athlete, coach or supporter.

\subsection{Correlations between Gender, Credibility and Dependent Variables}

Despite the lack of significant results for sportswriter gender's effect on the dependent variables, sportswriter credibility was slightly negatively correlated with reader gender (Table 7). Because reader gender was coded with females as 1 and males as 2 , this means female readers were slightly more likely to ascribe credibility to the sportswriter.

Because sportswriter gender was coded with no byline as 0 , females as 1 and males as 2, a one-way ANOVA was run to compare the means of all three conditions. A significant difference was found based on sportswriter gender $(F(2307)$ $=6.38, p<.01)$. Tukey's HSD was used to figure out the nature of the differences between sportswriter genders. Readers found the female sportswriter ( $m=5.87$, $s d=1.00)$ and no byline $(m=5.91, s d=1.03)$ to be more credible than the male sportswriter $(m=5.44, s d=1.11)$. There was no significant difference between female sportswriters and no byline.

There were also correlations between sportswriter credibility and perception of athlete (see Table 8).

Table 7. Correlation between gender of reader and sportswriter credibility.

\begin{tabular}{ccc}
\hline & Credibility \\
\hline Gender of reader & Pearson correlation & $-.17^{* *}$ \\
& Sig. (2-tailed) & .00 \\
$\mathrm{~N}$ & 310 \\
\hline
\end{tabular}

${ }^{* *} p<.01$.

Table 8. Correlation between perception of athlete and sportswriter credibility.

\begin{tabular}{ccc}
\hline & & Credibility \\
\hline Athleticism & Pearson correlation & $.54^{* *}$ \\
& Sig. (2-tailed) & .00 \\
Respectability & $\mathrm{N}$ & 310 \\
& Pearson correlation & $.63^{* *}$ \\
& Sig. (2-tailed) & .00 \\
Interest & $\mathrm{N}$ & 310 \\
& Pearson correlation & $.15^{* *}$ \\
& Sig. (2-tailed) & .01 \\
& $\mathrm{~N}$ & 310
\end{tabular}

${ }^{* *} p<.01$ 


\subsection{Regression Models of Credibility Correlations}

To give some context to the credibility correlations, simple linear regressions were calculated to predict perceptions of female athletes based on what readers thought of the sportswriters' credibility.

First, a simple linear regression was calculated to predict perceptions of athleticism based on sportswriter credibility. A significant regression equation was found $(F(1308)=128.62, p<.001)$, with an $R^{2}$ of .30 . Predicted athleticism of the athlete is equal to $3.48+.43$ (credibility), when athleticism and credibility are measured with the scales used in this study (see Table 9 for the coefficient and constant).

Second, a simple linear regression was calculated to predict perceptions of respectability based on sportswriter credibility. A significant regression equation was found $(F(1308)=198.54, p<.001)$, with an $R^{2}$ of .39 . Predicted respectability of the athlete is equal to $2.60+.56$ (credibility), when respectability and credibility are measured with the scales used in this study (see Table 10 for the coefficient and constant).

Third, a simple linear regression was calculated to predict interest in sport based on sportswriter credibility. A significant regression equation was found $(F(1308)=6.78, p<.001)$, with an $R^{2}$ of .02 . Predicted interest in the athlete and her sport is equal to $2.21+.24$ (credibility), when interest and credibility are measured with the scales used in this study. This was the weakest regression coefficient, which fits with the rest of the data analyses that show little or no effect of gender on interest (see Table 11 for the coefficient and constant).

\section{Discussion}

The premise of this study is that "the link between source and audience characteristics [would] be the crucial factor" in perception (Bochner, 1994, p. 70), in terms of how readers perceive female athletes. The study also asks whether sportswriter gender alone affects how readers perceive female athletes. However,

Table 9. Coefficients for linear regression model of credibility effect on athleticism.

\begin{tabular}{cccccc}
\hline \multirow{2}{*}{ Model } & \multicolumn{2}{c}{$\begin{array}{c}\text { Unstandardized } \\
\text { coefficients }\end{array}$} & $\begin{array}{c}\text { Standardized } \\
\text { coefficients }\end{array}$ & $\mathrm{t}$ & Sig. \\
\cline { 2 - 4 } & $\mathrm{B}$ & Std. Error & Beta & & \\
\hline (Constant) & 3.84 & .22 & & 17.48 & .00 \\
Credibility & .43 & .04 & .54 & 11.34 & .00 \\
\hline
\end{tabular}

Table 10. Coefficients for linear regression model of credibility effect on respectability.

\begin{tabular}{cccccc}
\hline \multirow{2}{*}{ Model } & \multicolumn{2}{c}{$\begin{array}{c}\text { Unstandardized } \\
\text { coefficients }\end{array}$} & $\begin{array}{c}\text { Standardized } \\
\text { coefficients }\end{array}$ & $\mathrm{t}$ & Sig. \\
\cline { 2 - 4 } & $\mathrm{B}$ & Std. Error & Beta & & \\
\hline (Constant) & 2.60 & .23 & .63 & 11.15 & .00 \\
Credibility & .56 & .04 & & 14.09 & .00 \\
\hline
\end{tabular}


Table 11. Coefficients for linear regression model of credibility effect on interest.

\begin{tabular}{cccccc}
\hline \multirow{2}{*}{ Model } & \multicolumn{2}{c}{$\begin{array}{c}\text { Unstandardized } \\
\text { coefficients }\end{array}$} & $\begin{array}{c}\text { Standardized } \\
\text { coefficients }\end{array}$ & $\mathrm{t}$ & Sig. \\
\cline { 2 - 4 } & $\mathrm{B}$ & Std. Error & Beta & & \\
\hline (Constant) & 2.21 & .55 & .15 & 4.06 & .00 \\
Credibility & .24 & .09 & & 2.60 & .01 \\
\hline
\end{tabular}

the data show that the predictor of reader perception of female athletes is more one-sided: perceptions depend on the gender of the reader, with female readers generally thinking more positively of female athletes than male readers.

Although the study explores whether Communication Accommodation Theory could help explain the nuanced reaction of audiences to male versus female sports reporters (Mastro et al., 2012), the lack of significant interactions provides no evidence for CAT applying to the gender of the sportswriter in this case. Similarly, there is slim evidence of persuasion based on similarity with the sources, even though gender is a signifier that acts "as a marker of similarity or dissimilarity with audience members" (Flanagin \& Metzger, 2003, p. 684).

The Elaboration Likelihood Model and heuristic processing does not appear to play into the results of this study, as White and Andsager's (1991) research suggested it would. White and Andsager found people prefer to hear arguments from members of their own groups; thus, males prefer columns written by men and females prefer columns written by women. Participants regarded columns written by writers of their own gender to be more interesting than columns written by the opposite gender, or they "ascribed interesting columns to writers of their own gender" (White \& Andsager, 1991, p. 718). But in this study, the only factors that significantly correlated with interest, with a Pearson coefficient greater than .20, were relevance and tennis participation (see Table 6). This suggests that experience with sports has more to do with interest than the gender of the reader or the sportswriter.

\subsection{Credibility}

In order to find salient covariates, sportswriter credibility was also tested. Although this was not directly part of the research question, a few correlations appeared regarding credibility. The results show female readers find sportswriters to be more credible, and female sportswriters are seen as more credible. When the sportswriter is rated as more credible, the female athlete is seen as more athletic, respectable and interesting.

As noted in the literature review, gender has a mixed research history as a credibility indicator, and these results echo portions of the literature. Despite their findings that readers found columns written by their own gender to be more interesting than columns written by someone of the opposite gender, White and Andsager (1991) found no difference between genders for columnist credibility, and no difference based on topic. Other researchers cite the same varying findings throughout the literature (Flanagin \& Metzger, 2003). 


\section{Possible Reasons Men Saw Sportswriters as Less Credible}

The fact that the female reader was slightly more willing to ascribe credibility to the sportswriter may mean that men, being the stereotypical sports experts, are less likely to ascribe credibility to sportswriters in general, or to ascribe credibility to sportswriters writing about female athletes. It could have to do with a generalized male confidence or the fact that the sport, tennis, is seen as gender neutral, rather than as a gendered sport. It could also have to do with regular sports media consumers distrusting unfamiliar sources; the results showed a correlation of $r=.27(p<.01)$ between relevance and reader gender.

\subsection{Limitations}

The fact that there were significant results for athleticism and respectability but not for interest could reflect the personal character nature of the athleticism and respectability scale items, as opposed to the reader-centric nature of the interest scale items. But even for athleticism and respectability, the differences in perception are slight, despite being significant.

A limitation of this study is that it only included bylines, which eliminated attractiveness confounds but failed to address the role of sportswriter gender at outlets (including blogs) where an author photo is published with each article or sports news is read out loud. Another limitation is that, to stay within time and financial constraints, this study only looked at perceptions of female athletes. A comparison with articles about male athletes would have added to the validity of the study. A study on the effects of sportswriter and reader gender on perceptions of male AND female athletes would provide a valuable addition to the literature. This line of research also will allow extrapolation to newsrooms that cover both men's and women's sports. And a study that included more sports would have allowed for some extrapolation to newsrooms that cover sports perceived as masculine, feminine or gender-neutral.

Sampling via a more universal survey system might also have added to the validity of the study; because Amazon Mechanical Turk is still fairly new, not as wide a portion of the population knows about it as other sampling methods. Still, these results should be generalizable to the computer-literate adult American population.

\subsection{Future Directions}

Male and female journalists should not worry that their names alone will affect how female athletes are perceived. Editors should realize that the gender of their sportswriters does not play a key role in how female athletes are perceived. The more pressing concern is the credibility of the sportswriter; female sportswriters are actually seen as more credible when writing about female athletes.

Because there is no interaction between sportswriter gender and reader gender when it comes to perceptions of female athletes' athleticism and respectability, editors can have more women write about female athletes for men's magazines 
and men write for women's magazines. The editors must realize, however, that depending on their primary audience, the female athlete may not be perceived as being as athletic or respectable. Therefore, magazines with primarily male audiences must be even more aware of and careful with framing, gendering, art and all qualitative aspects of presentation. In terms of hiring, this could mean looking for male and female writers with a proven track record of respectful coverage of women (both in published work and in comments made on social media).

But these suggestions come with an important caveat: If the results of this study dictate who reports on female athletes in the future, the current trends could become even more ground into our society. While this study shows correlations based on reader gender and writer credibility that does not mean that the status quo is acceptable and should be pursued. Rather, the underlying causes of these correlations must be identified, and a conversation must continue about how to fix negative cultural norms.

Areas for future study include looking at how the gender of sports broadcasters affects audience perception of athletes. This could affect broadcast and radio, multimedia and interactive journalism and even commentary and blogging. Further qualitative study could include interviewing editors about their assignment decisions and sportswriters about their views on the hierarchy of covering male or female sports.

In some ways, the insignificant results of this study are good news. The researcher expected to see a significant interaction between sportswriter and reader gender, as well as a significant impact of sportswriter gender on the dependent variables, and that was just not there. The lack of results could mean that there is more parity in sportswriter gender than expected. The lack of a correlation between sexism and the dependent variables could mean that readers with sexist ideals do not apply that attitude to female athletes in sports articles. The lack of a correlation between need for cognition and the dependent variables may mean that whether readers think hard about a brief female athletics article, they are likely to come to similar conclusions.

Even the significant results showed a small difference between perceptions of female athletes; the overall consensus was still positive about the athlete. But this means that in order to bring more balance to the world of sports, the media has to do more than slap a byline on a story. The debriefing on the study told participants that this study would try to find out whether it is better for male or female writers to write about female athletes, based on reader gender. The answer is unclear, partly because of insignificant results and partly because of the entrenchment a dichotomous answer could cause. Thus, further qualitative study is needed. Perhaps, in the meantime, more diversity in newsrooms would help level differences in perception based on attributes of the sportswriter.

\section{Conclusion}

As previously mentioned, implications of the findings obtained in this study are vast. Sportswriters must be aware of the various biases that influence their writ- 
ings about the performance and accomplishments of female athletes. As data obtained in this study implies, journalists, scholars, sports managers, sports promoters, reporters, announcers, and others involved in the sports news industry are not immune from inheriting the racial and gender biases of our society. According to the Women's Sports Foundation website, it has been recommended that sport journalists, reporters, media and editors do the following:

- Commit to Non-Sexist Communications.

- Pay careful attention to photos and words employed in all news stories. We do not believe that sexist language and image stereotyping intentional, but are asking for sportswriters to take a moment to reflect on the selection of words, images, and other ways that female athletes are framed in news stories.

- Participate in Required Inclusivity and Diversity Training Courses: Sportswriters and others interested in sport journalism industry must seek to take training courses with regard to sexist and racist language used in sports news coverage.

- Public Interest Stories. All print and electronic media are interested in public interest stories. Sports reporters should constantly write stories about athletes, especially women that go beyond looks, sexual objectification, body shape, ethnicity, and their violation of gender roles.

\section{References}

Armstrong, C. L., \& McAdams, M. J. (2009). Blogs of Information: How Gender Cues and Individual Motivations Influence Perceptions of Credibility. Journal of Computer-Mediated Communication, 14, 435-456. https://doi.org/10.1111/j.1083-6101.2009.01448.x

Bates, B. R., Romina, S., Ahmed, R., \& Hopson, D. (2006). The Effect of Source Credibility on Consumers' Perceptions of the Quality of Health Information on the Internet. Medical Informatics and the Internet in Medicine, 31, 45-52. https://doi.org/10.1080/14639230600552601

Bochner, S. (1994). The Effectiveness of Same-Sex versus Opposite-Sex Role Models in Advertisements to Reduce Alcohol Consumption in Teenagers. Addictive Behaviors, 19, 68-82. https://doi.org/10.1016/0306-4603(94)90053-1

Brann, M., \& Himes, K. L. (2010). Perceived Credibility of Male versus Female Television Newscasters. Communication Research Reports, 27, 243-252. https://doi.org/10.1080/08824091003737869

Brock, T. C. (1965). Communicator-Recipient Similarity and Decision Change. Journal of Personality and Social Psychology, 1, 650-654. https://doi.org/10.1037/h0022081

Cacioppo, J. T., \& Petty, R. E. (1982). The Need for Cognition. Journal of Personality and Social Psychology, 42, 116-131. https://doi.org/10.1037/0022-3514.42.1.116

Cacioppo, J. T., Petty, R. E., \& Kao, C. F. (1984). The Efficient Assessment of Need for Cognition. Journal of Personality Assessment, 48, 306-307. https://doi.org/10.1207/s15327752jpa4803_13

Chaiken, S., \& Ledgerwood, A. (2007). Heuristic Processing. In K. D. Vohs, R. F. Baumeister, \& Sage Publications (Eds.), Encyclopedia of Social Psychology (pp. 427-428). Thousand Oaks, CA: Sage Publications. https://doi.org/10.4135/9781412956253.n255

Crisci, R., \& Kassinove, H. (1973). Effect of Perceived Expertise, Strength of Advice, and 
Environmental Setting on Parental Compliance. Journal of Social Psychology, 89, 245-250. https://doi.org/10.1080/00224545.1973.9922597

Cronk, B. C. (2012). How to Use SPSS. Glendale, CA: Pyrczak.

Daniels, E. A. (2009). Sex Objects, Athletes, and Sexy Athletes: How Media Representations of Women Athletes Can Impact Adolescent Girls and College Women. Journal of Adolescent Research, 24, 399-422. https://doi.org/10.1177/0743558409336748

Daniels, E., \& Wartena, H. (2011). Athlete or Sex Symbol: What Boys Think of Media Representations of Female Athletes. Sex Roles, 65, 566-579. https://doi.org/10.1007/s11199-011-9959-7

DeMarree, K. G., \& Petty, R. E. (2007). Elaboration Likelihood Model. In K. D. Vohs, R. F. Baumeister, \& Sage Publications (Eds.), Encyclopedia of Social Psychology (pp. 280-283). Thousand Oaks, CA: Sage Publications. https://doi.org/10.4135/9781412956253.n172

Flanagin, A. J., \& Metzger, M. J. (2003). The Perceived Credibility of Personal Web Page Information as Influenced by the Sex of the Source. Computers in Human Behavior, 19, 683-701. https://doi.org/10.1016/S0747-5632(03)00021-9

Friedman, H. H., Santeramo, M. J., \& Traina, A. (1978). Correlates of Trustworthiness for Celebrities. Academy of Marketing Science, 6, 291. https://doi.org/10.1007/BF02732313

Glick, P., \& Fiske, S. T. (1996). The Ambivalent Sexism Inventory: Differentiating Hostile and Benevolent Sexism. Journal of Personality and Social Psychology, 70, 491-512. https://doi.org/10.1037/0022-3514.70.3.491

Greer, J. D., \& Jones, A. H. (2012). A Level Playing Field? Audience Perceptions of Male and Female Sports Analysts. International Journal of Interdisciplinary Social Sciences, 6, 67-79. https://doi.org/10.18848/1833-1882/CGP/v06i08/52137

Gunther, A., Kautz, D., \& Roth, A. (2011). The Credibility of Female Sports Broadcasters: The Perception of Gender in a Male-Dominated Profession. Human Communication, 14, 71-84.

Hovland, C. I., Janis, I. L., \& Kelley, H. H. (1953). Communication and Persuasion: Psychological Studies of Opinion Change. New Haven, CT: Yale University Press.

Kaiser, K. (2011). Gender Dynamics in Producing News on Equality in Sports: A Dual Longitudinal Study of Title IX Reporting by Journalist Gender. International Journal of Sport Communication, 4, 359-374. https://doi.org/10.1123/ijsc.4.3.359

Kian, E. M., \& Hardin, M. (2009). Framing of Sport Coverage Based on the Sex of Sports Writers: Female Journalists Counter the Traditional Gendering of Media Coverage. International Journal of Sport Communication, 2, 185-204. https://doi.org/10.1123/ijsc.2.2.185

Knight, J. L., \& Giuliano, T. A. (2001). He’s a Laker: She's a “Looker”: The Consequences of Gender-Stereotypical Portrayals of Male and Female Athletes by the Print Media. Sex Roles, 45, 217-229. https://doi.org/10.1023/A:1013553811620

Knight, J. L., \& Giuliano, T. A. (2003). Blood, Sweat, and Jeers: The Impact of the Media's Heterosexist Portrayals on Perceptions of Male and Female Athletes. Journal of Sport Behavior, 26, 272-284.

Lapchick, R., Burnett, C., Farris, M., Gossett, R., Orpilla, C., Phelan, J., Snively, D. et al. (2013). The 2012 Associated Press Sports Editors Racial and Gender Report Card. The Institute for Diversity and Ethics in Sport.

https://www.sensepublishers.com/media/1776-gender-relations-in-sport.pdf

Macharia, S., O’Connor, D., \& Ndangam, L. (2010). Who Makes the News? Global Media Monitoring Project 2010. Global Media Monitoring Project. 
http://cdn.agilitycms.com/who-makes-the-news/Imported/reports_2010/global/gmmp global_report_en.pdf

Mastro, D., Seate, A., Blecha, E., \& Gallegos, M. (2012). The Wide World of Sports Reporting: The Influence of Gender and Race-Based Expectations on Evaluations of Sports Reporters. Journalism \& Mass Communication Quarterly, 89, 458-474. https://doi.org/10.1177/1077699012447922

Morin, D. T., Ivory, J. D., \& Tubbs, M. (2012). Celebrity and Politics: Effects of Endorser Credibility and Sex on Voter Attitudes, Perceptions, and Behaviors. The Social Science Journal, 49, 413-420. https://doi.org/10.1016/j.soscij.2012.09.011

Ohanian, R. (1990). Construction and Validation of a Scale to Measure Celebrity Endorsers' Perceived Expertise, Trustworthiness, and Attractiveness. Journal of Advertising, 19, 39-52. https://doi.org/10.1080/00913367.1990.10673191

Ordman, V. L., \& Zillmann, D. (1994). Women Sports Reporters: Have They Caught up? Journal of Sport \& Social Issues, 18, 66-75. https://doi.org/10.1177/019372394018001005

Rodgers, S., \& Thorson, E. (2003). A Socialization Perspective on Male and Female Reporting. Journal of Communication, 53, 658-675.

https://doi.org/10.1111/j.1460-2466.2003.tb02916.x

Sprecher, S., \& Reis, H. T. (2009). Communication Accommodation Theory. In Encyclopedia of Human Relationships (pp. 265-267). Thousand Oaks, CA: SAGE Publications.

White, H. A., \& Andsager, J. L. (1991). Newspaper Column Readers' Gender Bias: Perceived Interest and Credibility. Journalism Quarterly, 68, 709-718.

https://doi.org/10.1177/107769909106800412 